Article

\title{
Short-Term Response of Soil Microbial Community to Field Conversion from Dryland to Paddy under the Land Consolidation Process in North China
}

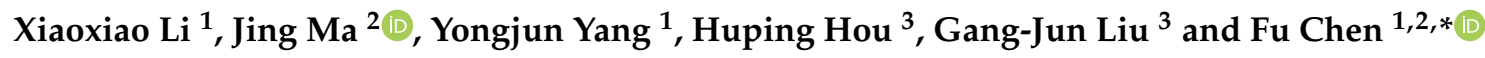 \\ 1 School of Environment Science and Spatial Informatics, China University of Mining and Technology, \\ Xuzhou 221043, China; lixiaoxiao@cumt.edu.cn (X.L.); y.yang@cumt.edu.cn (Y.Y.) \\ 2 Low Carbon Energy Institute, China University of Mining and Technology, Xuzhou 221008, China; \\ jingma2013@cumt.edu.cn \\ 3 Geospatial Science, College of Science, Engineering and Health, RMIT University, \\ Melbourne, VIC 3000, Australia; houhuping@cumt.edu.cn (H.H.); gang-jun.liu@rmit.edu.au (G.-J.L.) \\ * Correspondence: chenfu@cumt.edu.cn; Tel.: +86-5168-388-3501
}

Received: 31 July 2019; Accepted: 1 October 2019; Published: 4 October 2019

\begin{abstract}
Land consolidation of dryland-to-paddy conversion for improving tillage conditions and grain production capacity is widely implemented throughout the world. The conversion affects soil ecological stability, especially the most active soil microorganisms. However, the impacts of the dryland-to-paddy conversion has paid little attention in recent decades. In this study, a pot experiment was used to explore the responses of the microbial community and their interactions with soil properties after rice in the first season (five months). The results indicated that a significant decrease in the topsoil $\mathrm{pH}$, organic matter content, nitrate nitrogen, and ammonical nitrogen, and an increase in soil electrical conductivity (EC) was observed $(p<0.05)$ after the dryland-to-paddy conversion. The richness and diversity of bacteria and fungi decreased in the short term. The composition of the soil microbial community and the soil microbial dominant bacteria had considerably changed after the conversion. Actinobacteria, Firmicutes, and Olpidiomycota were found to be highly sensitive to the dryland-to-paddy conversion. The soil microbial community structure had extremely significant positive correlations with soil $\mathrm{pH}, \mathrm{EC}$, organic matter, nitrate nitrogen, and ammonical nitrogen $(p<0.05)$. Microorganisms are the most important component of soil nutrient cycling. Converting a large area of dryland to paddy may lead to an imbalance in the soil carbonitride cycle and should be further examined in North China.
\end{abstract}

Keywords: land consolidation; soil microorganisms; high-throughput sequencing; bacterial diversity; fungal diversity

\section{Introduction}

The soil carbon pool is the world's largest carbon pool in the terrestrial ecosystem [1-3]. Even a slight change in the soil can lead to huge changes in the global carbon cycle, and even create an imbalance $[4,5]$. Changes in the soil carbon pool are usually attributed to changes in land use, which are closely associated with human socioeconomic activities [6-8]. To cope with the rapid loss of agricultural land and food security issues, since 2000, the Chinese government has invested $\$ 436$ billion in large-scale land consolidation that has covered 30,000 hectares cumulatively, with North China accounting for approximately $60 \%$ of the land consolidation projects $[9,10]$. This large-scale land consolidation project has significantly impacted the agricultural ecological environment, such as the carbon cycle, coordination of soil and water utilization, and agricultural ecological services [11-14]. 
The most active components of the soil environment are the microorganisms that are critical for the nutrient cycling in soil [15-18]. Previous studies have shown that $58-90 \%$ of the carbon flux in the decomposition of soil organic matter (SOM) is produced by bacteria and fungi $[19,20]$. Microorganisms alter the soil development process and greenhouse gas emissions by affecting the decomposition and accumulation of organic matter (OM) in the soil [20]. Soil conversion affects the physiochemical properties and microbial community of agricultural soil [15], as well as soil carbon cycling [21]. Paddy rice agriculture provides the staple grain for almost half of China's population and the rice yield is higher than that of other crops [22]. Because of the current policy of protecting cultivated land "to compensate excellent land for excellent land taken" and "to compensate paddy field for paddy filed taken" by the Chinese government [23], some areas with superior hydrothermal conditions, such as sufficient rainfall, higher annual accumulated temperature, and flat terrain, are often converted from dryland to- paddy during the land consolidation process [22].

However, dry land and paddy fields are two distinct land uses, and they have significantly different impacts on the soil environment and the microbial community [24]. By changing the community structure of the soil, different tillage methods may result in different changes in soil biological richness and evenness [11,13]. The land consolidation of dryland-to-paddy conversion affects the soil environmental factors and the quality of the soil matrix, which eventually affects the diversity and functioning of the soil microbial community [25-27]. The large-scale conversion of dryland to paddy would inevitably alter the local soil environment or even a large area of agricultural land, and affect the physicochemical properties and biological processes of the soil [11-13], thus directly or indirectly affecting the agroecosystem carbonitride cycle and the emissions of greenhouse gases such as $\mathrm{CO}_{2}, \mathrm{CH}_{4}$, and $\mathrm{N}_{2} \mathrm{O}$ [17]. Dryland-to-paddy conversion would impact the ground surface radiation balance and ground surface temperature because of the difference in land cover, thus affecting the regional climate characteristics [22,28]. Yu et al. hypothesized that land consolidation is an important measure to implement for meeting human food demand by increasing cultivated areas; however, concomitantly, the other ecosystem services are weakened, such as landscape diversity, which may cause a series of ecological problems, such as biomass decreases, thereby threatening the biodiversity [29].

Since 2000, China has conducted large-scale land consolidations, with the initial goal of supplementing arable land and increasing food production capacity [30-34]. In 2008, the Chinese government demanded "a large-scale implementation of rural land consolidation" and emphasized on improving the quality of cultivated land [23]. After 2013, the ecological transformation of land consolidation became a national agenda [30-32]. To meet the increasing demands on rice production because of the growing population, paddy rice agriculture has been expanding to the northern regions of China [22]. The conversion of dryland to paddy through land consolidation has become a common phenomenon in North China. Although previous studies have evaluated various aspects, the socio-economic objective of land consolidation has been long overstated [33], and little attention has been paid to its potential negative impacts on the ecological environment. In this study, the change in soil microbial community after dryland-to-paddy conversion and its relationship with the soil environment were investigated through simulation experiments and high-throughput sequencing technology. These findings are expected to provide a basis for the formulation of policies related to land consolidation, intensive agriculture, and technology advancements for the dryland-to-paddy conversion implemented by the Chinese government.

\section{Materials and Methods}

\subsection{Experimental Field and Design}

The studied areas were the South Lake Campus of the China University of Mining and Technology, Xuzhou, Jiangsu, China $\left(117^{\circ} 08^{\prime} 08^{\prime \prime} ; \mathrm{E}\right.$ and $\left.34^{\circ} 12^{\prime} 31^{\prime \prime} \mathrm{N}\right)$. The climate is warm temperate semi-humid monsoon with four distinct seasons every year and abundant sunlight. The annual average temperature 
is $14^{\circ} \mathrm{C}$, the average annual precipitation is $841.2 \mathrm{~mm}$, and the frost-free period is 209 days [34]. Xuzhou is a part of the North China Plain and is a traditional wheat-corn rotation area. Affected by factors like soil salinization, drought, and farmland fragmentation, Xuzhou faces high agricultural vulnerability [35]. Xuzhou has been vigorously promoting land consolidation by converting dryland to paddy to upgrade farmland water conservancy facilities and to improve the stability of agricultural production.

The dryland to paddy conversion was simulated in the experimental fields of the Land Science Research Center, located in the South Lake Campus of China University of Mining and Technology (Xuzhou, Jiangsu, China), from June to November 2018. These fields had been in use for wheat-corn planting for the previous five years. It belonged to the agricultural ecosystem with wheat-corn planting. The soil composition was cinnamon fluvo-aquic with a sand-silt-clay ratio of 15.12:22.34:9.15:53.39 [34]. We set up two groups of pot experiments: one group planting corn (CK1) and the other group planting rice (PF1). We set up three sets of parallel experiments. CK0 were the original six soil samples, all from dryland. Three of them named CK0-D, were the soil samples before CK1 pot experiment as a control for CK1. The other three named CK0-P were the soil samples before PF1 pot experiment as a control for PF1. The potting device was a polyethylene (PE) bucket. The height of all buckets was $60 \mathrm{~cm}$, and the thickness of the soil layer in the tank was $40 \mathrm{~cm}$. When moving the soil, we did not disturb the soil and the original tillage layer was not damaged. The upper pot width of the corn pot was $45 \mathrm{~cm}$, the width of the lower diameter was $40 \mathrm{~cm}$. The upper pot width of the rice pot was $50 \mathrm{~cm}$ and the width of the lower diameter was $40 \mathrm{~cm}$. The PF1 surface soil was maintained flat and moist, and the outdoor flooding was only conducted once the soil was stable and compact. On 13 June 2018, we planted corn into buckets, with five corn plants transplanted per bucket, row spacing $300 \mathrm{~mm}$, and plant spacing $200 \mathrm{~mm}$. On the same day, rice was transplanted into the bucket, with four rice plants transplanted per bucket, row spacing $300 \mathrm{~mm}$, and plant spacing $200 \mathrm{~mm}$. The rice was shallow-irrigated maintaining an average water layer of $40 \mathrm{~mm}$, which is the recommended standard in North China. The irrigation water was tap water, in accordance with Chinese agricultural irrigation standards. One group was used for planting Nonghua 101 corn variety. The other group was submerged for five days and then planted with the rice Sterile Peduncle 31 variety (Figure 1).

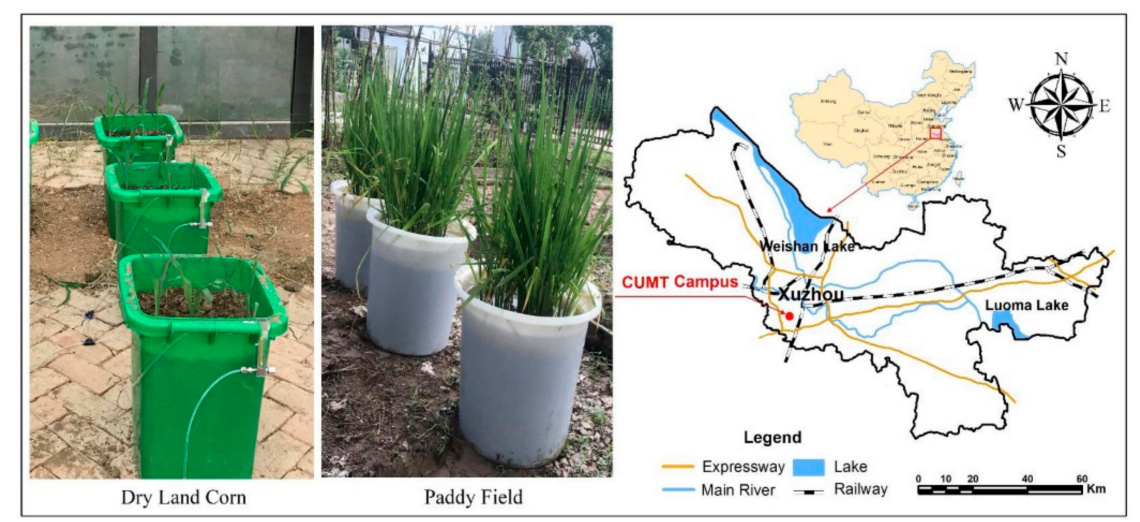

Figure 1. Location and photos of the experimental field.

\subsection{Soil Sample Collection and Analysis}

The first soil samples collected from two groups of experimental buckets on 13 June 2018, were labeled as CK0-D and CK0-P. Then, corn was planted in three experimental buckets (CK1), and rice was transplanted in another three experimental buckets (PF1). On 13 November 2018, a five-spot random sampling method was used to collect nearly $500 \mathrm{~g}$ of $0-20 \mathrm{~cm}$ mixed topsoil samples. In total, there were four groups with three repeats in each group for a total of 12 soil samples. The soil samples were sealed in sterile Ziploc (Hopebio Bio-Tcehnology Co., Ltd, Qingdao, China) bags and brought back to the laboratory immediately. One part of the soil samples was dried at room temperature for about 1 week, cleaned to remove gravel and animal and plant residues, then ground and filtered with 
a 2-mm sieve to determine the basic physicochemical properties of the soil sample. Another part of the fresh soil samples was used directly for biodiversity analysis.

We choose soil $\mathrm{pH}$, electrical conductivity (EC), SOM, ammonical nitrogen, nitrate nitrogen, available phosphorus (AP), and available potassium (AK) as factors to assess the impacts of the dryland-to-paddy conversion on soil ecological environment. These soil physicochemical properties are important indicators of soil fertility and soil nutrient cycling. At the same time, these indicators are also limiting factors for agricultural productivity under the land consolidation process in China [11,36]. Briefly, the soil $\mathrm{pH}$ and EC were measured using potentiometric methods (water:soil = 1:2.5) [34]. The SOM was determined by the potassium dichromate and external heating method [37]. The ammonical nitrogen was determined by potassium chloride extraction and distillation method [37], and the nitrate nitrogen was determined by the phenol disulphonic acid spectrophotometric method [37]. The AP was determined by the ammonium bicarbonate extraction and molybdenum antimony anti-colorimetric method [37], and the AK was determined by the ammonium acetate extraction and flame photometer method (FP640, Jingke, Shanghai, China) [37]. Each indicator per soil sample was measured three times, and the average value was calculated.

\subsection{DNA Purification, PCR amplification, and High-Throughput Sequencing}

Total DNA was extracted from the soil microorganisms using a FastDNATM SPIN Kit for Soil (MP Biomedicals, CA, USA) according to the kit instructions, generating a total of 12 DNA samples from the dryland and paddy fields. The concentration and purity of the total DNA extracts were determined using NanoDrop (ND-100, Molecular Devices, CA, USA). After the DNA extraction, the V4 and V5 regions of bacterial 16S rDNA were amplified using the primers 515F (5'-GTGCCAGCMGCCGCGGTAA-3'), and 907R (5'-CCGTCAATTCMTTTRAGTTT- $\left.3^{\prime}\right)$. The amplification of standard fungal ITS1 (internal transcribed spacer 1 ) was amplified using the primers ITS5F (5'-GGAAGTAAGTCGTAACAAGG-3'), and ITS1R ( $5^{\prime}$-GCTGCGTTCTTCTCGATGC-3'). The PCR amplification procedure was as follows: pre-denaturation at $98^{\circ} \mathrm{C}$ for $2 \mathrm{~min}$; denaturation at $98^{\circ} \mathrm{C}$ for $15 \mathrm{~s}$, annealing at $55^{\circ} \mathrm{C}$ for $30 \mathrm{~s}$, extension at $72{ }^{\circ} \mathrm{C}$ for $30 \mathrm{~s}$, for a total of 25 cycles; a final extension at $72{ }^{\circ} \mathrm{C}$ for $5 \mathrm{~min}$; and hold at $10{ }^{\circ} \mathrm{C}$. The PCR amplification products were detected by gel electrophoresis on a $2 \%$ agarose gel, and the target fragments were recovered using a DNA gel extraction kit (Axygen, CA, USA). Based on the preliminary quantitative results of electrophoresis, the PCR amplification products were subjected to fluorescence quantification using a Quant-iT PicoGreen dsDNA Assay Kit (MP Biomedicals, CA, USA) and read using a quantitative instrumentation microplate reader (BioTek FLx800, Vermont, USA). Based on the fluorescence quantitation results, the samples were mixed in a ratio according to the sequencing amount required for each sample. A TruSeq Nano DNA LT Library Prep Kit (Illumina, CA, USA) was used to construct the soil microbial sequencing library. After quantification with Qubit and Q-PCR (quantitative real time polymerase chain reaction), the constructed library was sequenced with HiSeq2500 PE2500 (Illumina, CA, USA) [27].

\subsection{Data Analysis and Processing}

First, the raw sequence data were split and filtered to generate valid data. The qualified sequencing sequences are then diluted by the above-mentioned sequencing, mixed according to the required sequencing amount. Purified amplicons were pooled in equimolar amounts and paired-end sequenced $(2 \times 300)$ on the Illumina MiSeq platform (Personalbio, Shanghai, China), according to the protocol. The sample sequencing data were distinguished with the barcode sequence, and the sequence of each sample underwent quality control. Then the non-specific amplification sequences and chimeric were removed with the usearch method (http://www.drive5.com/usearch/). Then, based on the valid data, the operational taxonomic unit (OTU) clustering and annotation were conducted to produce the OTUs, and the results of the basic analysis of the classification spectrum of each sample were obtained. A rarefaction curve for OTUs with $97 \%$ similarity was generated using the usearch method $[17,34]$. Bacterial 16S rRNA gene was identified using Greengenes database (Release 13.8, 
http://greengenes.secondgenome.com/) [38]. The fungal ITS sequence of fungi uses the UNITE database (Release 5.0, https://unite.ut.ee/) [39].

The Simpson index, Chao 1 index, abundance-based coverage estimator (ACE), and Shannon index were used to demonstrate the richness and evenness of a single sample community. The $\alpha$ diversity was calculated through the galaxy platform (http://mem.rcees.ac.cn:8080). PCA was used to identify the primary characteristics of the soil microbial community distribution and to quantify the similarities and differences in microorganisms between groups, which is the $\beta$ diversity. SPSS 20.0 (IBM, New York, USA) was used to conduct the Duncan analysis, which was used for multiple correlation analysis. Origin 9.0 (Origin Lab, Massachusetts, USA) was used to prepare the microbial community abundance plots at various levels. R-project (R Development Core Team, Vienna, Austria) was used to conduct the Mantel test. $R$ vegan package ( $R$ Development Core Team, Vienna, Austria) was used to prepare the plots of microbial community structure and redundancy analysis (RDA) for the soil environment.

\section{Results and Analysis}

\subsection{Impact of Dryland-to-Paddy Conversion on Soil Physicochemical Properties}

We found no significant differences in the soil physiochemical properties between the wheatand corn-planted soil samples (CK0-D, CK0-P, and CK1), indicating that their soil properties were similar. Significant differences were observed in some soil properties between the soil samples before and after the short-term land consolidation (CK0-P and PF1, respectively). The dryland-to-paddy conversion considerably impacted the soil properties. Except for EC, the soil $\mathrm{pH}, \mathrm{SOM}$, nitrate nitrogen, and ammonical nitrogen of PF1 were lower compared to those of CK0-P, and the standard deviations of these indicators for PF1 were less than those of CK0-P. When the indicators were considered individually, the dryland-to-paddy conversion impacted soil $\mathrm{pH}, \mathrm{EC}, \mathrm{SOM}$, nitrate nitrogen, and ammonical nitrogen the most $(p<0.05)$. The soil acidity increased and the SOM decreased significantly after planting rice $(p<0.05)$. Conversely, the soil EC significantly increased after the conversion and was as high as $31.54 \mathrm{mS} \cdot \mathrm{cm}^{-3}$ for PF1, significantly different from that of CK0-P by $45.31 \%$. Soil available P and available $\mathrm{K}$ exhibited a decreasing trend that was not significant. In summary, continuous dryland planting did not significantly affect the soil properties. However, the standard deviation of soil property indicators was reduced after dryland-to-paddy conversion. We thought that short-term flooding increases the flow of soil nutrients, resulting in a homogeneous distribution. Thus, the conversion of dryland-to-paddy had some impact on the soil physicochemical properties in the short-term (Table 1).

Table 1. Description of soil physicochemical properties before and after the conversion of dryland to paddy.

\begin{tabular}{|c|c|c|c|c|}
\hline \multirow{2}{*}{ Soil Properties } & \multicolumn{2}{|c|}{ Dry Land Before Experiment } & \multirow{2}{*}{$\begin{array}{l}\text { Dry Land } \\
\text { Corn CK1 }\end{array}$} & \multirow{2}{*}{ Paddy Field PF1 } \\
\hline & CK0-D & CK0-P & & \\
\hline $\mathrm{pH}$ & $8.62 \pm 0.13 b$ & $8.43 \pm 0.23 b$ & $8.65 \pm 0.06 b$ & $8.15 \pm 0.01 a$ \\
\hline $\mathrm{EC}\left(\mathrm{mS} \cdot \mathrm{cm}^{-3}\right)$ & $17.25 \pm 8.94 a$ & $16.85 \pm 4.96 a$ & $15.13 \pm 3.68 \mathrm{a}$ & $31.54 \pm 2.72 b$ \\
\hline $\mathrm{SOM}\left(\mathrm{g} \cdot \mathrm{kg}^{-1}\right)$ & $23.00 \pm 3.51 b$ & $21.55 \pm 7.12 b$ & $21.10 \pm 2.42 b$ & $13.05 \pm 1.19 a$ \\
\hline $\mathrm{NN}\left(\mathrm{mg} \cdot \mathrm{kg}^{-1}\right)$ & $4.59 \pm 0.26 b$ & $4.14 \pm 0.43 b$ & $4.31 \pm 0.52 b$ & $3.30 \pm 0.27 a$ \\
\hline $\mathrm{AN}\left(\mathrm{mg} \cdot \mathrm{kg}^{-1}\right)$ & $1.33 \pm 0.15 b$ & $1.33 \pm 0.17 b$ & $1.36 \pm 0.20 b$ & $0.93 \pm 0.07 a$ \\
\hline $\mathrm{AK}\left(\mathrm{mg} \cdot \mathrm{kg}^{-1}\right)$ & $30.88 \pm 8.79 a$ & $30.41 \pm 8.67 a$ & $29.51 \pm 2.74 a$ & $23.25 \pm 1.58 \mathrm{a}$ \\
\hline $\mathrm{AP}\left(\mathrm{mg} \cdot \mathrm{kg}^{-1}\right)$ & $77.89 \pm 6.54 a$ & $76.22 \pm 4.79 a$ & $68.82 \pm 7.61 \mathrm{a}$ & $76.59 \pm 2.62 a$ \\
\hline
\end{tabular}

Note: Data are mean \pm standard deviation. Values in the same row with the same letter(s) are not significantly different per the Duncan analysis at $p<0.05$ between different treatments. SOM, soil organic matter; NN, nitrate nitrogen; AN, ammonical nitrogen; AP, available P; AK, available K. CKO-D is the soil sample before CK1 pot experiment as a control for CK1, CK0-P is the soil sample before PF1 pot experiment as a control for PF1, CK1 is the soil sample before corn harvest, and PF1 is the soil sample before rice harvest. The same below. 


\subsection{Impact of Dryland-to-Paddy Conversion on Soil Microbial Community}

The study was conducted using the Illumina Miseq high-throughput sequencing platform. The OTUs at $97 \%$ similarity were statistically analyzed for microbial information. A total of 418,946 sequences of soil bacteria were detected from the 12 soil samples. There were 107,079, 101,975, 106,596, 104,194, and 103,296 valid sequences detected from CK0-D, CK0-P, CK1, and PF1, respectively. The bacterial average OTU numbers of the dryland CK0-D, CK0-P, and CK1 were 9138, 9241, and 9502, respectively, slightly higher than those of the paddy fields PF1 at 8086.

After processing and analysis, a total of 655,620 valid soil fungi sequences were detected. A total of 157,263, 138,888, 183,410, and 176,059 valid sequences were detected from CK0-D, CK0-P, CK1, and PF1, respectively. The fungal OTU numbers of the dryland CK0-D, CK0-P, and CK1 were 3236, 3787, and 3816, respectively, and those for the paddy field PF1 was 2191. The number of OTUs in all the PF1 samples at the phylum, class, order, genus, and species level were significantly lower than those in the drylands $(p<0.05)$. Preliminary analysis showed that after the dryland-to-paddy conversion, the soil fungal species decreased compared to the drylands. Thus, the conversion may inhibit the development of fungi in the short term.

\subsubsection{Impact of Dryland-to-Paddy Conversion on Microbial Community Structure and Diversity}

In this study, we used $\alpha$ diversities for analyzing the soil microbial richness and diversity. The Chao 1 and ACE indices were used to reflect the community richness, and the Shannon index and Simpson index were used to reflect the community diversity. The $\alpha$ diversities of soil microorganisms before and after the land consolidation are listed in Table 2. In a short period, the microbial diversity significantly decreased after the dryland-to-paddy conversion. There was no significant difference in soil bacterial diversity between the dryland CK0-D, CK0-P, and CK1, although the microbial diversity indices of the paddy field PF1 reduced significantly. In detail, compared with CK0-P, the Simpson index decreased by $0.35-1.54 \%$, and the Shannon index decreased by $3.62-13.18 \%$.

Table 2. Impacts of the dryland-to-paddy conversion on soil microbial diversity.

\begin{tabular}{|c|c|c|c|c|c|}
\hline \multirow{2}{*}{$\begin{array}{c}\text { Sequencing } \\
\text { Type }\end{array}$} & \multirow{2}{*}{$\begin{array}{l}\text { Diversity } \\
\text { Index }\end{array}$} & \multicolumn{2}{|c|}{ Dry Land Before Experiment } & \multirow{2}{*}{$\begin{array}{l}\text { Dry Land } \\
\text { Corn CK1 }\end{array}$} & \multirow{2}{*}{$\begin{array}{c}\text { Paddy Field } \\
\text { PF1 }\end{array}$} \\
\hline & & CKO-D & CK0-P & & \\
\hline \multirow{4}{*}{ Bacteria } & Chao1 & $2396 \pm 348 a$ & $2528 \pm 720 a$ & $2771 \pm 654 a$ & $2297 \pm 748 a$ \\
\hline & $\mathrm{ACE}$ & $2472 \pm 419 a$ & $2578 \pm 725 a$ & $2818 \pm 650 a$ & $2338 \pm 757 a$ \\
\hline & Shannon & $10.03 \pm 0.20 b$ & $9.99 \pm 0.30 b$ & $10.10 \pm 0.24 b$ & $9.22 \pm 0.43 a$ \\
\hline & Simpson & $0.997 \pm 0.00 \mathrm{~b}$ & $0.997 \pm 0.00 \mathrm{~b}$ & $0.997 \pm 0.00 \mathrm{~b}$ & $0.989 \pm 0.07 a$ \\
\hline \multirow{4}{*}{ Fungus } & Chao1 & $345.25 \pm 116.2 \mathrm{a}$ & $364.09 \pm 104.8 \mathrm{a}$ & $406.8 \pm 83.0 \mathrm{a}$ & $243.9 \pm 66.8 \mathrm{a}$ \\
\hline & $\mathrm{ACE}$ & $345.45 \pm 115.3 a$ & $364.05 \pm 105.1 \mathrm{a}$ & $407.1 \pm 91.0 \mathrm{a}$ & $244.5 \pm 66.0 \mathrm{a}$ \\
\hline & Shannon & $6.28 \pm 0.45 b$ & $6.12 \pm 0.35 b$ & $5.64 \pm 0.54 b$ & $4.56 \pm 0.43 a$ \\
\hline & Simpson & $0.955 \pm 0.03 b$ & $0.957 \pm 0.03 b$ & $0.933 \pm 0.04 \mathrm{ab}$ & $0.858 \pm 0.68 a$ \\
\hline
\end{tabular}

Note: Data are mean \pm standard deviation. Values in the same row with the same letter(s) are not significantly different per the Duncan analysis at $p<0.05$ between different treatments.

After the dryland-to-paddy conversion, the fungal Simpson index decreased by $5.97-14.62 \%$, and the fungal Shannon index decreased by $21.38-32.07 \%$, with an average decline of $25.49 \%$. The conversion had a considerable impact on the Shannon index, and the difference was significant $(p<0.05)$. The soil microbial evenness decreased after the conversion as did the diversity and richness of soil bacteria and fungi in the short term. We found that the bacterial diversity was significantly changed compared to fungal diversity. Possibly because from the sequencing data, the unclassified sequence in the fungus was higher than the bacteria. And fungal classification and identification techniques are weaker than bacteria according to current sequencing technology.

PCA was conducted to assess the community composition of each sampling site at the genus level before and after the soil conversion. The results are shown in Figure 2. Points colored differently indicate 
different samples (groups). The closer the two points, the more similar the microbial community structure, and smaller the difference. The PCA demonstrated that the microbial community in PF1 was different from that of the other three groups, whereas the soil bacterial composition structure was very similar between the two CKs.
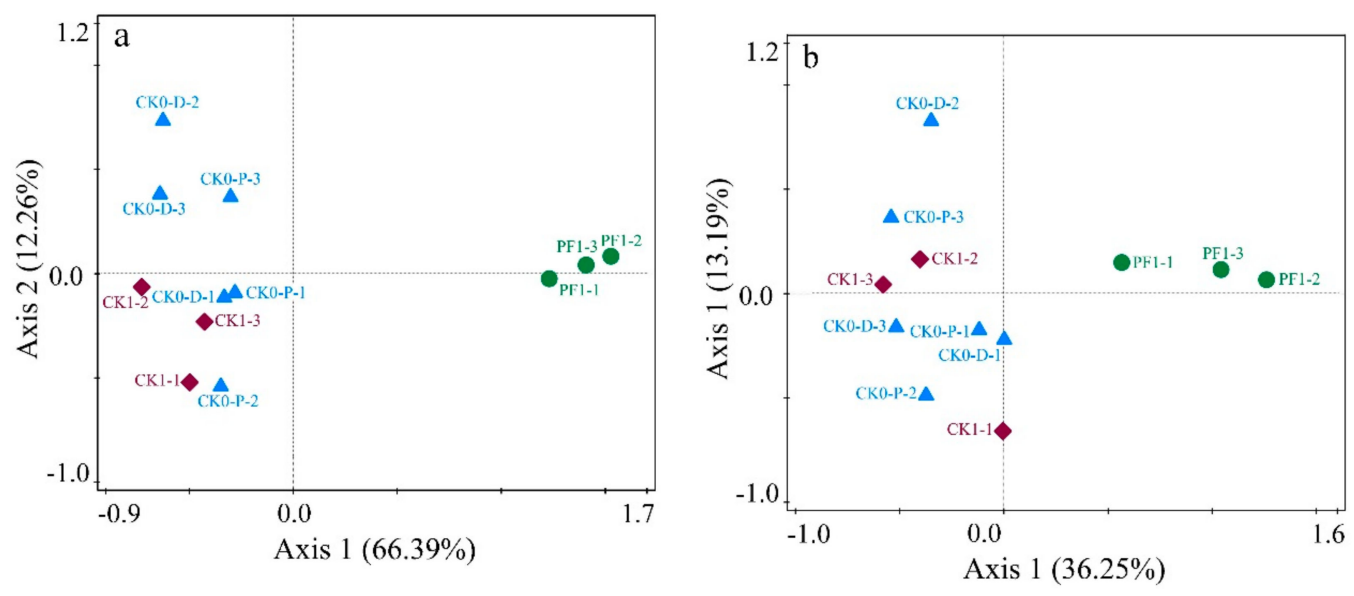

Figure 2. Principal component analysis (PCA) of soil (a) bacteria and (b) fungi at the genus level in the dryland-to-paddy conversion process. CK0-D is the soil sample before CK1 pot experiment, CK0-P is the soil sample before PF1 pot experiment, CK1 is the soil sample before corn harvest, and PF1 is the soil sample before rice harvest.

\subsubsection{Impact of Dryland-to-Paddy Conversion on the Soil Microbial Community Composition}

In the tested soils, $95 \%$ of the sequences from all the samples could be clearly classified. A total of 38 bacterial phyla were identified, of which the nine most abundant phyla accounted for more than $90 \%$ of the total relative abundance. These nine phyla included Proteobacteria, Acidobacteria, Chloroflexi, Firmicutes, Actinobacteria, Bacteroidetes, Gemmatimonadetes, Planctomycetes, and Verrucomicrobia, of which the Proteobacteria was the most abundant at $32.78 \%$ (Figure 3).

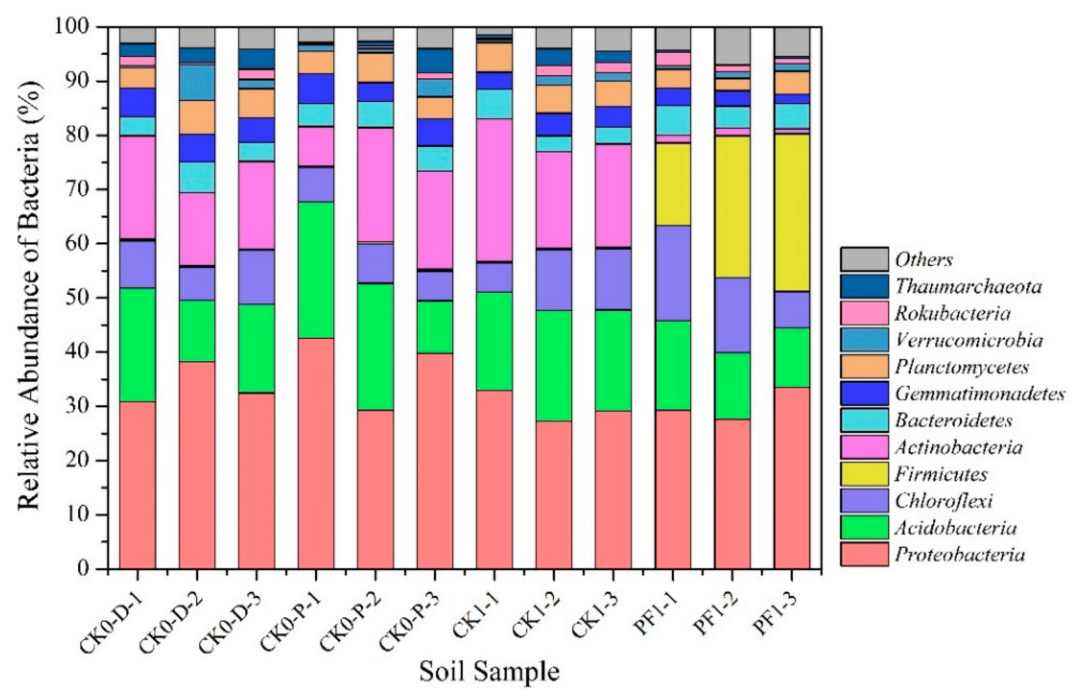

Figure 3. Changes in the relative abundance of bacterial phyla in the dryland-to-paddy conversion process.

Although we observed no remarkable difference in bacterial abundance between CK0-D, CK0-P, and CK1, the phylum composition of PF1 was different from the CKs, indicating that the land consolidation impacted the composition of the bacterial community. Actinobacteria favor neutral or 
slightly alkaline and aerated soils [26,40]. Compared to the loose drylands, the soils of PF1 provided a significantly anaerobic environment after the conversion of dryland to paddy. The relative abundance of bacterial phyla changed considerably after the conversion of dryland to paddy. The Actinobacteria completely disappeared while the Firmicutes appeared in the PF treatment. The relative abundance of Actinobacteria declined from $16.27 \%$ before planting rice to $1.23 \%$, a 13.23 -fold decline. Under the submerged anaerobic environment after the conversion, the relative abundance of anaerobic phyla like Chloroflexi and Firmicutes in PF1 increased, with the most significant change in Firmicutes, increasing from $0.23 \%$ to $23.50 \%$ during the conversion.

At the phylum level, 14 and 16 fungal phyla were identified from the drylands and paddy fields, respectively. The relative abundance of the six major phyla, including Ascomycota, Basidiomycota, Mortierellomycota, Rozellomycota, Chytridiomycota, and Olpidiomycota, accounted for $77.82 \%$, among which the most abundant was Ascomycota at 33.01\% (Figure 4). Similar to the bacterial abundance, the phylum composition of PF1 was significantly different from those of CK0-D, CK0-P, and CK1. Under the submerged environment after the conversion, the relative abundance of aerobic fungi like Ascomycota and Chytridiomycota decreased. Among them, we found a relatively exclusive appearance of the Chytridiomycota in CK0-D-1. The relative abundance of fungi was different from the other two CK0 treatments. The CK0-D-1 sample after planting corn was recorded as CK1-1, in which "Others" accounted for a large proportion. The relative abundances of Ascomycota in drylands and paddy fields were significantly different at $17.67 \%$ and $18.33 \%$, respectively, after the conversion of dryland to paddy. Among them, the increase in Olpidiomycota was the most significant. With a relative abundance of $0.07 \%$ as a rare fungal phylum in CK0-D, the abundance of Olpidiomycota changed drastically to $10.00 \%$ in PF1 as a dominant phylum and can therefore be considered a sensitive phylum for studying the succession of microbial diversity. Previous studies have shown that soil $\mathrm{pH}$ and SOM were the dominant factors affecting the microbial community structure and diversity [41,42]. Hence, the differences in the microbial community structure of the 12 samples were probably related to the soil environmental factors.

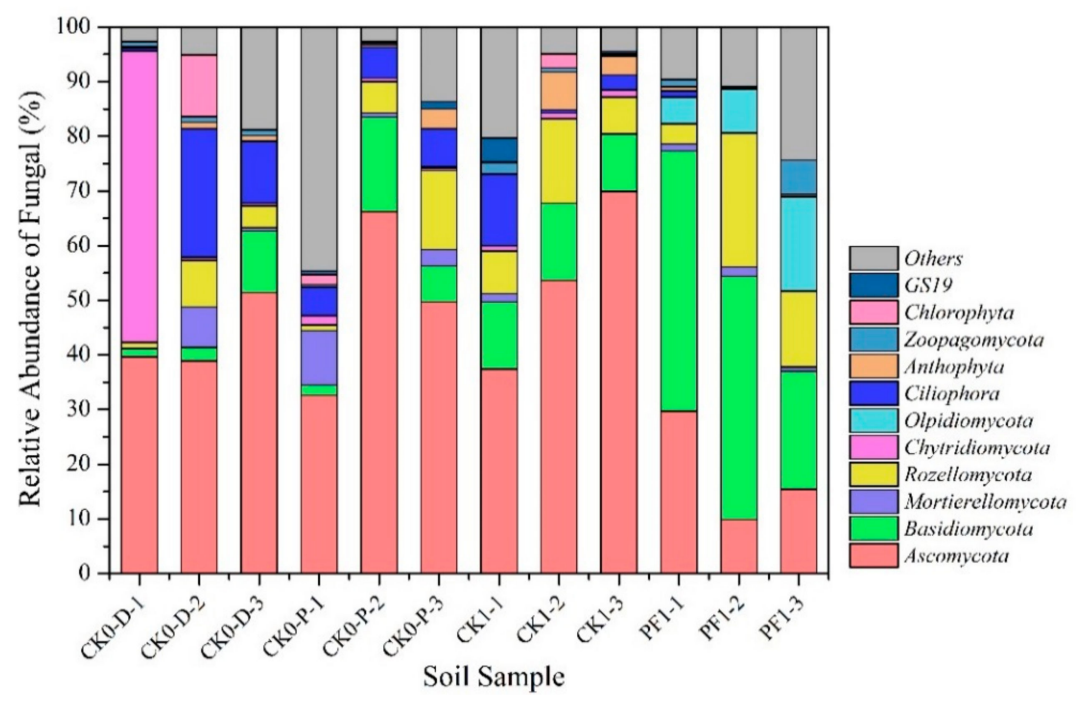

Figure 4. Changes in the relative abundance of fungal phyla in the dryland-to-paddy conversion process.

\subsection{Impact of Soil Physicochemical Properties on the Microbial Community Structure of Consolidated Soil}

To determine the chief environmental factors driving the microbial community, the Mantel test was conducted for the soil microorganisms and for the soil properties of the corresponding sampling sites before and after the conversion at the OTU level (Table 3). The structure demonstrated that the microbial population was correlated with EC and $\mathrm{pH}$ at high significance $(p<0.05)$. Microbial population was significantly correlated with $\mathrm{pH}$, and bacteria and fungi the correlation coefficients 
were 0.538 , and 0.367 (Table 3). As an important indicator of soil salinity and acid-base level, soil pH had a significant impact on the differentiation of bacterial and fungal community structures. The other factors significantly affecting the microbial community structure for both bacteria and fungi were SOM, nitrate nitrogen, ammonical nitrogen, and the soil nutrient index.

Table 3. Mantel test analysis of microorganisms and soil environment factors at the operational taxonomic unit (out) level.

\begin{tabular}{cccccc}
\hline \multicolumn{3}{c}{ Bacteria } & \multicolumn{3}{c}{ Fungi } \\
\hline Variable & $\boldsymbol{r}$ & $\boldsymbol{p}$ & Variable & $\boldsymbol{r}$ & $\boldsymbol{p}$ \\
\hline $\mathrm{pH}$ & 0.538 & $0.004^{* *}$ & $\mathrm{pH}$ & 0.367 & $0.013^{*}$ \\
$\mathrm{EC}$ & 0.576 & $0.002^{* *}$ & $\mathrm{EC}$ & 0.484 & $0.004^{* *}$ \\
$\mathrm{SOM}$ & 0.438 & $0.006^{* *}$ & $\mathrm{SOM}$ & 0.345 & $0.014^{*}$ \\
$\mathrm{NN}$ & 0.359 & $0.021^{*}$ & $\mathrm{NN}$ & 0.408 & $0.004^{* *}$ \\
$\mathrm{AN}$ & 0.351 & $0.012^{*}$ & $\mathrm{AN}$ & 0.393 & $0.007^{* *}$ \\
$\mathrm{AP}$ & -0.282 & $0.967^{*}$ & $\mathrm{AP}$ & -0.202 & 0.912 \\
$\mathrm{AK}$ & 0.253 & $0.039^{*}$ & $\mathrm{AK}$ & 0.167 & 0.126 \\
\hline
\end{tabular}

Note: ${ }^{* *}$ and ${ }^{*}$ mean significant difference at $5 \%$ and $10 \%$, respectively. SOM, soil organic matter; NN, nitrate nitrogen; AN, ammonical nitrogen; $\mathrm{AP}$, available $\mathrm{P} ; \mathrm{AK}$, available $\mathrm{K}$.

To further study the relationship between soil microbial phyla and soil properties, RDA was conducted, and the results are shown in Figures 5 and 6. Axis 1 and Axis 2 of the bacterial RDA were $68.43 \%$ and $14.09 \%$, respectively, and Axis 1 and Axis 2 of the fungal RDA were $37.25 \%$ and $14.50 \%$, respectively, which are both highly interpretable. The sampling points from the consolidated PF1 group behaved remarkably different from the other sampling points. All sampling points of PF1 demonstrated clear clustering with well-separated clusters. Both the bacterial and fungal communities in the drylands and paddy fields exhibited significant correlations with $\mathrm{pH}$ and EC. Except for EC, all relevant environmental factors were negatively correlated with the soil conversion of dryland to paddy.
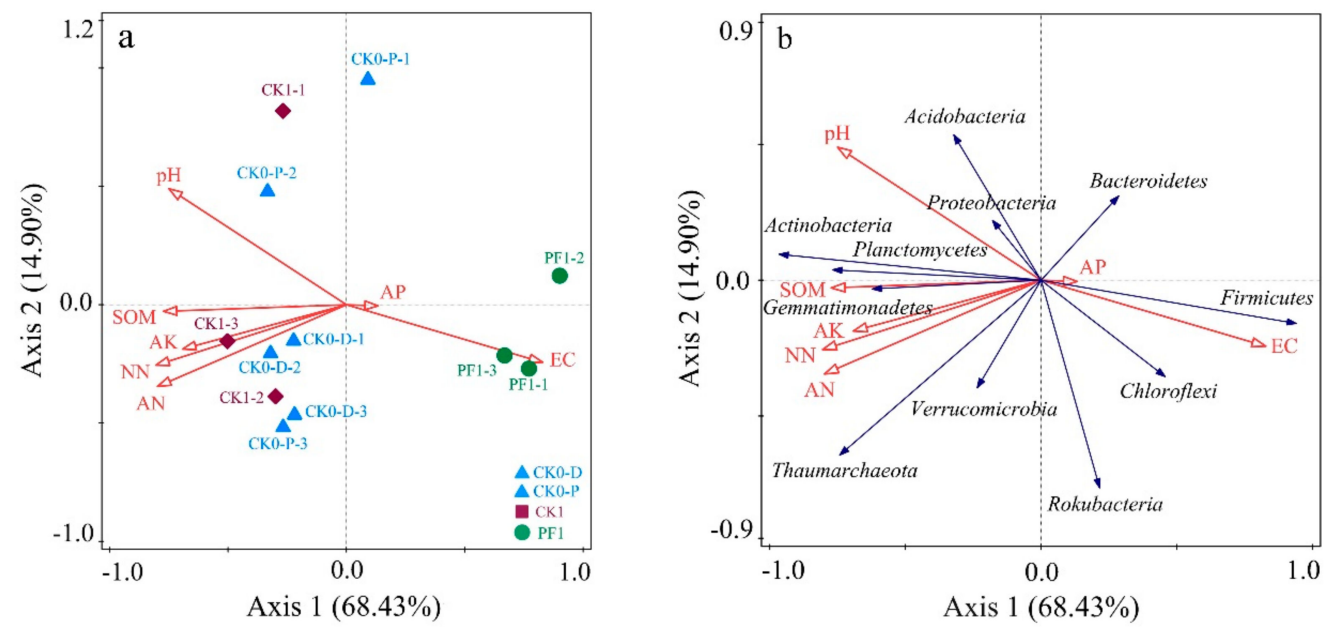

Figure 5. RDA (redundancy analysis) of (a) soil samples and the environmental factors and (b) chief bacterial phyla and the environmental factors. 

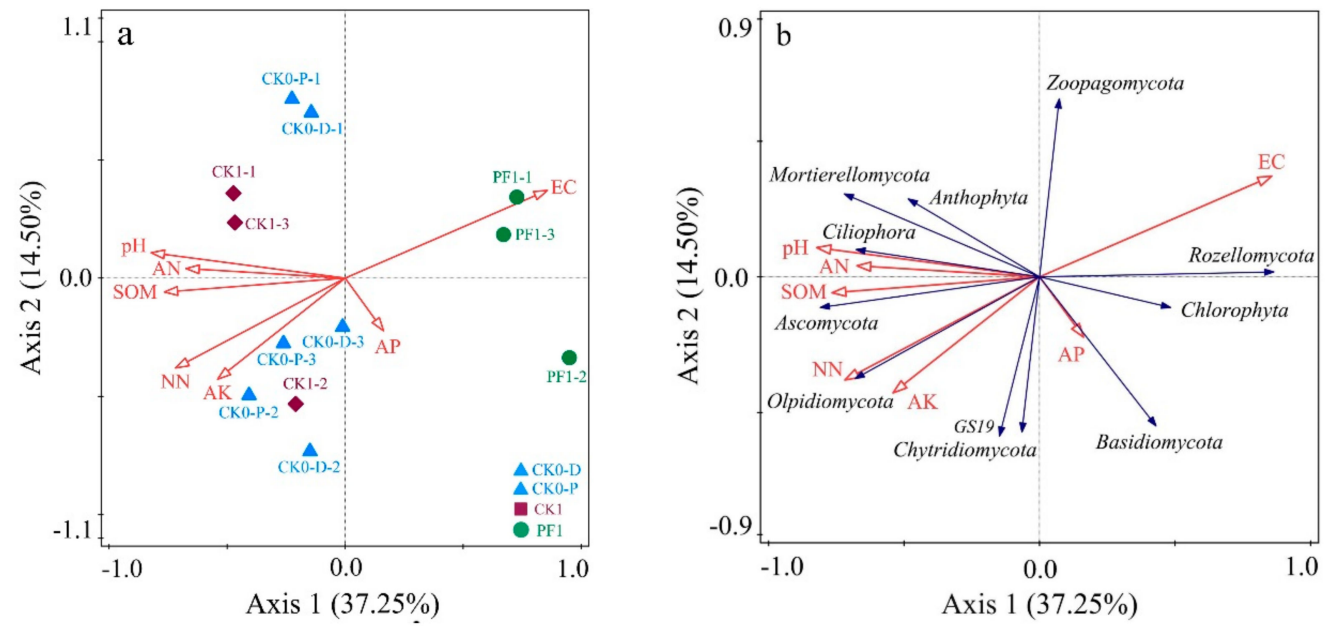

Figure 6. RDA of soil fungal community structure and soil environmental factors: (a) soil samples and the environmental factors; (b) chief fungal phyla and the environmental factors.

When the bacterial community of the soil (Figure 5a) was considered, EC lay on the second axis, preferably explaining the differences in community between drylands and paddy fields. Besides $\mathrm{pH}$ and EC, SOM, nitrate nitrogen, and ammonical nitrogen were also important factors affecting the microbial community structure. The correlation is indicated by the cosine value of the angle between a species and an environmental factor. As shown in Figure 5b, the soil EC had a highly positive correlation with Firmicutes, which was negative with Actinobacteria and Planctomycetes. The soil $\mathrm{pH}$ exhibited a strongly negative correlation with Chloroflexi. These results may explain the increase in EC and decrease in $\mathrm{pH}$ and SOM after land consolidation, resulting in dramatically decreased Actinobacteria and a substantial increase in Chloroflexi and Firmicutes, thus causing differences in the bacterial community.

Upon analyzing the soil fungal community, the $\mathrm{pH}, \mathrm{EC}, \mathrm{SOM}$, nitrate nitrogen, and ammonical nitrogen of soil were found to be positively correlated with the relative abundance of the community structure. The soil EC is represented by the longest arrows in Figure 5, indicating that, as an essential environmental factor, EC led to community differentiation. The first axis explains the differences in the community structure of the drylands and the paddy fields. As shown in Figure 6, soil EC was correlated positively with Chlorophyta and Rozellomycota, and negatively with Olpidiomycota. Soil pH, SOM, and nitrate nitrogen were correlated positively with Ascomycota, Ciliophora, and Mortierellomycota. The differences in the soil physicochemical properties caused by soil environmental changes because of the conversion of dryland to paddy resulted in a decrease in the abundance of Ascomycota and Mortierellomycota and a substantial increase in Rozellomycota, driving the diversity differences in the fungal community.

\section{Discussion}

\subsection{Impact of Conversion of Dryland to Paddy on Soil Eco-Environment}

Land consolidation has now become China's largest undertaking to change the land use structure, affect farmland ecological services $[36,43]$ and is essentially a process of ecological reconstruction. A slight change in the soil environment may lead to profound changes in the global environment [44]. The conversion of dry agricultural lands to paddy agriculture has become a common practice under the land consolidation policy. Changes in planting method and tillage practices would have a considerable impact on soil micro-ecology [45]. The soil hydrothermal and aeration conditions change with the conversion of dryland-to-paddy, thereby affecting the mineralization and humification of SOM. Water is the carrier of soil salt, and flooding treatment has a significant impact on EC. The leveling and merging of land and various field management measures are all considered important factors stimulating the 
soil micro-ecological changes in the conversion of dryland to paddy $[25,46]$. Brye et al. reported a major change in soil physicochemical properties as a result of land consolidation, consistent with our results [13]. As mentioned in Table 1, the soil physicochemical properties before and after the conversion differed significantly. The $\mathrm{pH}$ range of CK0 were 8.42-8.74, extremely significantly different from the paddy fields after the conversion $(p<0.001)$. The rice and paddy fields produce more $\mathrm{CO}_{2}$ and $\mathrm{CH}_{4}$. In general, the acid gases, like $\mathrm{CO}_{2}$ and $\mathrm{CH}_{4}$, had the most obvious effect on soil $\mathrm{pH}$ in accordance with the conclusion of Oppermann et al., who stated that the introduction of acid gases would cause the $\mathrm{pH}$ to drop [47].

In ecosystems, the cycling of elements like carbon and nitrogen is a coupled and complex process affected by various interactive factors [48]. In land consolidation, humans interfere with ecological processes and cause changes in soil physicochemical factors, thereby affecting the carbonitride cycling in an agroecosystem. Compared with dry land, paddy fields are submerged for a long time. Most of the soil voids are occupied with water, have low soil oxygen and redox potential, and reduced soil activity $[18,49]$. Therefore, we suggest that the reason that carbon, nitrogen, and phosphorus contents of paddy fields in this study were lower than those of dry land was the changes in the soil environmental conditions. Different tillage methods and management practices lead to changes in soil moisture and profound changes in the soil redox potential, affecting the form and availability of phosphorus in soil. In this study, the average AP contents in CK0-P and PF1 were 77.89 and 76.59, respectively, not consistent with the finding of Mulqueen et al. who stated that submergence was conducive to the release of soil phosphorus [50]. The primary reason may be the redistribution of soil phosphorus in plants-soil-microorganisms under different land-use patterns so that the soil AP was reduced after the dryland-to-paddy conversion.

\subsection{Changes in Microbial Community Structure and Function After the Dryland-to-Paddy Conversion}

Soil microorganisms are sensitive to changes in land use and the environment [51,52]. We found no significant changes in the microbial diversity of soils with dryland planting of corn. However, the microbial diversity significantly decreased in the short term after the conversion of dryland to paddy, and the Simpson and Shannon indices were all lower in PF1 than in three CKs $(p<0.05)$. Microorganisms in the soil have certain selective adaptability to the soil environment and are closely associated with its environmental factors $[41,53]$. The Mantel test and RDA results showed that the change in planting method altered the soil physiochemical properties after the conversion, which led to significant changes in the structure of the soil microbial community. Among the soil physiochemical factors, soil $\mathrm{pH}$ and $\mathrm{EC}$ were dominant, affecting the microbial community. Changes in soil moisture altered the oxygen condition of the soil. Therefore, the submerged rice fields had lower oxygen concentrations, inhibited growth of soil aerobes, and enhanced survival of anaerobes and facultative anaerobes, such as denitrificans and methanogens, leading to variations in microbial community composition and diversity [54]. Likewise, Drenovsky et al. found huge differences in the soil microbial community structure between aerobic and submerged conditions, consistent with our results [42]. Sahrawat et al. found that submerged conditions were not conducive to the mineralization and transformation of soil organic carbon and suppressed the carbon supply capacity of the soil, thus affecting the soil microbial composition [55].

Bacteria are the most diverse microbial populations in soil and are extremely sensitive to environmental variations [56]. Similar to most agricultural soils [15], the phylum Proteobacteria was the most dominant at $32.78 \%$. The primary function of Proteobacteria is organic nitrogen fixation, and can adapt well to various complex environments [57]. Actinobacteria grow vigorously in environments with higher $\mathrm{OH}^{-}$concentrations [40]. After the conversion, the $\mathrm{pH}$ of the paddy field was lower than that of the dry land; therefore, Actinobacteria richness was significantly higher in the consolidated paddy fields. Chloroflexi and Firmicutes are often detected in anaerobic sludge [58]. After the conversion of dryland to- paddy, Chloroflexi showed a significantly increased relative abundance. Chloroflexi are facultative anaerobes that can produce energy through photosynthesis using $\mathrm{CO}_{2}$ as a carbon source, generating 
no oxygen in the process, and converting $\mathrm{CO}_{2}$ into soil inert carbon at lower nutrient conditions [58]. The dramatic changes in the farmland soil environment before and after the land consolidation greatly affected the soil carbonitride cycling of which microorganisms are a part. Firmicutes are anaerobic redox bacteria. Their growth is positively related with temperature within a certain range [59]. Under the submerged conditions after the conversion of dryland to paddy, the small differences between day and night temperatures, with higher average temperature than that of the drylands in the same period, may be the cause of the significantly higher abundance of Firmicutes in the paddy fields than in the drylands [59].

The composition of soil fungi dominant bacteria had considerably changed after the dryland-to-paddy conversion. In the CK0-D, CK0-P, and CK1 groups, Ascomycota was the most dominant phylum at $48.82 \%$ significantly different from PF1. The most dominant phylum in PF1 was Basidiomycota, which mostly grow in damp environments of rotten woods and compost piles [60]. This also implied that the change of soil anaerobic environment after the conversion of dryland to paddy was more conducive to the growth of Basidiomycota. We found that soil nitrogen content in PF1 was less than the three CKs, and this was different from the change of Basidiomycota. However, Sterkenburg et al. [61] found that Basidiomycota are positively correlated with the soil nitrogen content, inconsistent with our findings. We supported that Basidiomycetes are affected by many factors, such as soil temperature, humidity, and physicochemical properties $[15,60]$. Not only because of changes in soil conditions, but also the role of microbes is subtle $[27,56]$. In this study, the composition of the soil microbial community and diversity index of fungi are different from those in dry land. This may be due to differences in the microbial community structure and a combined result of various soil environmental factors [41,60]. Fungi constitute most of the soil microbial biomass, are the bearers of material circulation and energy exchange playing an important role in the carbonitride cycle [16]. Because of the differences in fungal composition, organic matter decomposition in dry land and paddy fields may have a large difference. In this study, $13.07 \%$ of sequences were unclassified, indicating that many fungal species need to be further identified and classified.

\subsection{Uncertainty of Ecological ilmpacts of Dryland-to-Paddy Conversion}

To comply with the farmland construction standards and with the policies of "compensating excellent land for excellent land taken" and "compensating paddy fields for paddy fields taken," the conversion of dryland to paddy has become common in China's land consolidation. By adjusting the existing cropping patterns and a series of engineering measures for field leveling, irrigation facilities, and soil, the original low-yielding, low income, and disaster-prone drylands can be transformed into high-quality better-yielding paddy fields. As an important source of greenhouse gas emissions, rice fields seriously threaten global climate changes [62]. Whereas the conversion of dryland to paddy ensures food security, further global climate change challenges could be created. The global warming potential (GWP) of $\mathrm{CH}_{4}$ is 25-fold of that of $\mathrm{CO}_{2}$, and the GWP of $\mathrm{N}_{2} \mathrm{O}$ is 298-fold of that of $\mathrm{CO}_{2}$ [63]. Some scholars have shown that because paddy fields are favored, the growth of anaerobic methanogens promote the emission of $\mathrm{CH}_{4}$ [64-66]. In addition, compared with dry land, rice fields produce more $\mathrm{N}_{2} \mathrm{O}$ [67]. Large areas of conversion of drylands to paddy fields may ensure the safeguard food security, but may lead to the production of greenhouse gases and potentially create ecological risks.

Since sunlight, temperature, and water requirements of various crops are different, paddy rice can only be cultivated in areas with good hydrothermal conditions. In response to the requirements of national macroeconomic policies, the North China Plain and the Northeast Plain have extensively undertaken dryland-to-paddy conversion projects. As a result, well-irrigated rice fields are common, severely challenging the safety of groundwater resources [68]. The groundwater consumption by agricultural practices in the North China Plain is the primary reason for the decline in the groundwater level and the formation of groundwater funnels in the past 40 years [22,69]. The paddy fields in the Northeast Plain have increased by $120 \%$ (from 2.5 to 5.5 million hectares). The continuous expansion 
of paddy fields is posing enormous ecological risks to the northeast region, which has limited water resources and a relatively fragile wetland ecosystem [70].

The large-scale expansion of agricultural irrigation has led to changes in surface radiation and energy balance, thus affecting the ground humidity and temperature [71-73]. Kang and Eltahir [28] showed that the expansion of irrigated agriculture in the North China Plain has facilitated surface evaporation, increased the exposure of the surface to radiation, and affected the surface temperature and humidity, thereby increasing the intensity of heat waves, intensifying summer high-temperature extremes, and accelerating global climate change. The large-scale expansion of dryland-to-paddy conversion has increased pressure on regional water resources, increased environmental changes, and the resulting ecological problems need to be fully evaluated. In the future, water-efficient irrigation should be aggressively used to improve the efficiency of water-use, thus enabling the sustainable development of land and water resources. Conversely, effective emission reduction measures based on various factors should be undertaken, and temporospatial dynamic monitoring should be used to evaluate the ecological effects because of the dryland-to-paddy conversion. These will help encourage low-carbon agriculture and promote food security and the sustainable development of arable land, which are essential for mitigating the challenges of global climate change.

\section{Conclusions}

Land consolidation of dryland-to-paddy conversion for improving grain production capacity is widely implemented throughout the world. However, few studies have focused on the impact of this process on the soil environment. Therefore, a simulation experiment was used to determine the impacts of the dryland-to-paddy consolidation on soil microbial community. The results showed that soil $\mathrm{pH}, \mathrm{SOM}$, nitrate nitrogen, and ammonical nitrogen decreased and soil EC increased in a short time because of the conversion of dryland to paddy. After the dryland-to-paddy conversion, the soil microbial richness and diversity decreased, and the soil microbial community composition and relative abundance changed significantly in the short term. The relative abundance of Actinobacteria, Firmicutes, and Olpidiomycota varied widely and could be used as sensitive microorganisms indicating microbial diversity succession in the conversion. Moreover, the changes of soil environmental factors including $\mathrm{pH}, \mathrm{EC}, \mathrm{SOM}$, nitrate nitrogen, and ammonical nitrogen were the primary reasons leading to the changes in the soil microbial community structure. Land consolidation of dryland-to-paddy conversion may alter the soil organic carbon decomposition and $\mathrm{CH}_{4}$ emission. These potential negative impacts on soil environment should be paid attention to achieve sustainable intensive agriculture and mitigate aggravating global warming.

Author Contributions: Conceptualization, X.L. and F.C.; methodology, J.M.; software, Y.Y.; validation, X.L., F.C., and J.M.; formal analysis, H.H. and G.-J.L.; investigation, X.L. and H.H.; resources, F.C.; data curation, Y.Y.; writing—original draft preparation, X.L.; writing—review and editing, F.C.; visualization, Y.Y.; supervision, F.C. and J.M.; project administration, G.-J.L.; funding acquisition, F.C.

Funding: This research was funded by the Key Projects in the National Science \& Technology Pillar Program during the Twelfth Five-year Plan Period, grant number 2015BAD06B02.

Acknowledgments: The authors would like to thank Land consolidation Centre of Jiangsu Province for the support during the research. The authors would also like to thank MDPI English Service for providing linguistic assistance during the preparation of this manuscript.

Conflicts of Interest: The authors declare no conflict of interest. The funders had no role in the design of the study; in the collection, analyses, or interpretation of data; in the writing of the manuscript, and in the decision to publish the results.

\section{References}

1. Lal, R. Soil carbon sequestration impacts on global climate change and food security. Science 2004, 304, $1623-1627$. [CrossRef] [PubMed]

2. Akala, V.; Lal, R. Potential of mine land reclamation for soil organic carbon sequestration in Ohio. Land Degrad.Dev. 2015, 11, 289-297. [CrossRef] 
3. Lyu, M.; Xie, J.; Ukonmaanaho, L.; Jiang, M.; Li, Y.; Chen, Y.; Yang, Z.; Zhou, Y.; Lin, W.; Yang, Y. Land use change exerts a strong impact on deep soil C stabilization in subtropical forests. J. Soils Sediments 2017, 17, 2305-2317. [CrossRef]

4. Cox, P.M.; Betts, R.A.; Jones, C.D.; Spall, S.A.; Totterdell, I.J. Acceleration of global warming due to carbon-cycle feedbacks in a coupled climate model. Nature 2000, 408, 184-187. [CrossRef] [PubMed]

5. Crowther, T.W.; Todd-Brown, K.E.; Rowe, C.W.; Wieder, W.R.; Carey, J.C.; Machmuller, M.B.; Snoek, B.; Fang, S.; Zhou, G.; Allison, S.D. Quantifying global soil carbon losses in response to warming. Nature 2016, 540, 104. [CrossRef] [PubMed]

6. Arneth, A.; Sitch, S.; Pongratz, J.; Stocker, B.; Ciais, P.; Poulter, B.; Bayer, A.; Bondeau, A.; Calle, L.; Chini, L. Historical carbon dioxide emissions caused by land-use changes are possibly larger than assumed. Nat. Geosci. 2017, 10, 79. [CrossRef]

7. Luo, Z.; Wang, E.; Baldock, J.; Xing, H. Potential soil organic carbon stock and its uncertainty under various cropping systems in Australian cropland. Soil Res. 2014, 52, 463-475. [CrossRef]

8. Wu, H.; Guo, Z.; Gao, Q.; Peng, C. Distribution of soil inorganic carbon storage and its changes due to agricultural land use activity in China. Agric. Ecosyst. Environ. 2009, 129, 413-421. [CrossRef]

9. Jin, X.; Shao, Y.; Zhang, Z.; Resler, L.M.; Campbell, J.B.; Chen, G.; Zhou, Y. The evaluation of land consolidation policy in improving agricultural productivity in China. Sci. Rep. 2017, 7, 2792. [CrossRef]

10. Jin, X.; Ding, N.; Zhang, Z.; Zhou, Y.; Yang, X. Inter-provincial allocation of land consolidation fund and effects of land consolidation in China. Trans. Chin. Soc. Agric. Eng. 2012, 28, 1-9.

11. Sharifi, A.; Gorji, M.; Asadi, H.; Pourbabaee, A.A. Land leveling and changes in soil properties in paddy fields of Guilan province, Iran. Paddy Water Environ. 2014, 12, 139-145. [CrossRef]

12. Brye, K.R.; Slaton, N.A.; Norman, R.J. Soil Physical and Biological Properties as Affected by Land Leveling in a Clayey Aquert. Soil Sci. Soc. Am. J. 2006, 70, 631-642. [CrossRef]

13. Brye, K.R.; Slaton, N.A.; Mozaffari, M.; Savin, M.C.; Norman, R.J.; Miller, D.M. Short-Term Effects of Land Leveling on Soil Chemical Properties and Their Relationships with Microbial Biomass. Soil Sci. Soc. Am. J. 2004, 68, 924-934. [CrossRef]

14. Crecente, R.; Alvarez, C.; Fra, U. Economic, social and environmental impact of land consolidation in Galicia. Land Use Policy 2002, 19, 135-147. [CrossRef]

15. Legrand, F.; Picot, A.; Cobo-Díaz, J.F.; Carof, M.; Chen, W.; Le Floch, G. Effect of tillage and static abiotic soil properties on microbial diversity. Appl. Soil Ecol. 2018, 132, 135-145. [CrossRef]

16. Ma, A.; Zhuang, X.; Wu, J.; Cui, M.; Lv, D.; Liu, C.; Zhuang, G. Ascomycota members dominate fungal communities during straw residue decomposition in arable soil. PLoS ONE 2013, 8, e66146. [CrossRef]

17. Liu, J.; Sui, Y.; Yu, Z.; Shi, Y.; Chu, H.; Jin, J.; Liu, X.; Wang, G. Soil carbon content drives the biogeographical distribution of fungal communities in the black soil zone of northeast China. Soil Biol. Biochem. 2015, 83, $29-39$. [CrossRef]

18. Bardgett, R.D.; Freeman, C.; Ostle, N.J. Microbial contributions to climate change through carbon cycle feedbacks. ISME J. 2008, 2, 805-814. [CrossRef]

19. Hopkins, D.; Sparrow, A.; Gregorich, E.; Novis, P.; Elberling, B.; Greenfield, L. Redistributed lacustrine detritus as a spatial subsidy of biological resources for soils in an Antarctic dry valley. Geoderma 2008, 144, 86-92. [CrossRef]

20. Zechmeister-Boltenstern, S.; Keiblinger, K.M.; Mooshammer, M.; Peñuelas, J.; Richter, A.; Sardans, J.; Wanek, W. The application of ecological stoichiometry to plant-microbial-soil organic matter transformations. Ecol. Monogr. 2015, 85, 133-155. [CrossRef]

21. Kolis, K.; Hiironen, J.; Riekkinen, K.; Vitikainen, A. Forest land consolidation and its effect on climate. Land Use Policy 2017, 61, 536-542. [CrossRef]

22. Dong, J.; Xiao, X.; Zhang, G.; Menarguez, M.; Choi, C.; Qin, Y.; Luo, P.; Zhang, Y.; Moore, B. Northward expansion of paddy rice in northeastern Asia during 2000-2014. Geophys. Res. Lett. 2016, 43, 3754-3761. [CrossRef] [PubMed]

23. Yan, J.; Xia, F.; Bao, H.X.H. Strategic planning framework for land consolidation in China: A top-level design based on SWOT analysis. Habitat Int. 2015, 48, 46-54. [CrossRef]

24. Suleiman, A.K.A.; Manoeli, L.; Boldo, J.T.; Pereira, M.G.; Roesch, L.F.W. Shifts in soil bacterial community after eight years of land-use change. Syst. Appl. Microbiol. 2013, 36, 137-144. [CrossRef] [PubMed]

25. Yu, Q.; Zeng, Q.; Yu, G. The influence of land consolidation on biomass and ecological environment. Res. J. Appl. Sci. Eng. Technol. 2014, 7, 3656-3662. [CrossRef] 
26. He, X.Y.; Su, Y.R.; Liang, Y.M.; Chen, X.B.; Zhu, H.H.; Wang, K.L. Land reclamation and short-term cultivation change soil microbial communities and bacterial metabolic profiles. J. Sci. Food Agric. 2012, 92, 1103-1111. [CrossRef] [PubMed]

27. Hu, X.; Liu, J.; Wei, D.; Zhu, P.; Cui, X.A.; Zhou, B.; Chen, X.; Jin, J.; Liu, X.; Wang, G. Effects of over 30-year of different fertilization regimes on fungal community compositions in the black soils of northeast China. Agric. Ecosys. Environ. 2017, 248, 113-122. [CrossRef]

28. Kang, S.; Eltahir, E.A. North China Plain threatened by deadly heatwaves due to climate change and irrigation. Nat. Commun. 2018, 9, 2894. [CrossRef]

29. Yu, G.; Feng, J.; Che, Y.; Lin, X.; Hu, L.; Yang, S. The identification and assessment of ecological risks for land consolidation based on the anticipation of ecosystem stabilization: A case study in Hubei Province, China. Land Use Policy 2010, 27, 293-303. [CrossRef]

30. Liu, Y.; Wang, J.; Long, H. Analysis of arable land loss and its impact on rural sustainability in Southern Jiangsu Province of China. J. Environ. Manag. 2010, 91, 646-653. [CrossRef]

31. Long, H. Land consolidation: An indispensable way of spatial restructuring in rural China. J. Geogr. Sci. 2014, 24, 211-225. [CrossRef]

32. Chen, F.; Yu, M.; Zhu, F. Rethinking Rural Transformation Caused by Comprehensive Land Consolidation: Insight from Program of Whole Village Restructuring in Jiangsu Province, China. Sustainability 2018, 10, 2029. [CrossRef]

33. Du, X.; Zhang, X.; Jin, X. Assessing the effectiveness of land consolidation for improving agricultural productivity in China. Land Use Policy 2018, 70, 360-367. [CrossRef]

34. Chen, F.; Zhang, W.; Ma, J.; Yang, Y.; Zhang, S.; Chen, R. Experimental study on the effects of underground $\mathrm{CO}_{2}$ leakage on soil microbial consortia. Int. J. Greenh. Gas. Control. 2017, 63, 241-248. [CrossRef]

35. Mao, Y.; Sang, S.; Liu, S.; Jia, J. Spatial distribution of $\mathrm{pH}$ and organic matter in urban soils and its implications on site-specific land uses in Xuzhou, China. Comptes Rendus Biol. 2014, 337, 332-337. [CrossRef]

36. Li, X.; Yu, M.; Ma, J.; Luo, Z.; Chen, F.; Yang, Y. Identifying the Relationship between Soil Properties and Rice Growth for Improving Consolidated Land in the Yangtze River Delta, China. Sustainability 2018, 10, 3072. [CrossRef]

37. Schoeneberger, P.J. Field Book for Describing and Sampling Soils; USDA Natural Resources Conservation Service: Lincoln, NE, USA, 1998.

38. DeSantis, T.Z.; Hugenholtz, P.; Larsen, N.; Rojas, M.; Brodie, E.L.; Keller, K.; Huber, T.; Dalevi, D.; Hu, P.; Andersen, G.L. Greengenes, a chimera-checked 16S rRNA gene database and workbench compatible with ARB. Appl. Environ. Microbiol. 2006, 72, 5069-5072. [CrossRef]

39. Kõljalg, U.; Nilsson, R.H.; Abarenkov, K.; Tedersoo, L.; Taylor, A.F.; Bahram, M.; Bates, S.T.; Bruns, T.D.; Bengtsson-Palme, J.; Callaghan, T.M. Towards a unified paradigm for sequence-based identification of fungi. Mol. Ecol. 2013, 22, 5271-5277. [CrossRef]

40. Barka, E.A.; Vatsa, P.; Sanchez, L.; Gaveau-Vaillant, N.; Jacquard, C.; Klenk, H.-P.; Clément, C.; Ouhdouch, Y.; van Wezel, G.P. Taxonomy, physiology, and natural products of Actinobacteria. Microbiol. Mol. Biol. Rev. 2016, 80, 1-43. [CrossRef]

41. Rousk, J.; Bååth, E.; Brookes, P.C.; Lauber, C.L.; Lozupone, C.; Caporaso, J.G.; Knight, R.; Fierer, N. Soil bacterial and fungal communities across a pH gradient in an arable soil. ISME J. 2010, 4, 1340-1351. [CrossRef]

42. Drenovsky, R.; Vo, D.; Graham, K.; Scow, K. Soil water content and organic carbon availability are major determinants of soil microbial community composition. Microb. Ecol. 2004, 48, 424-430. [CrossRef] [PubMed]

43. Zhang, Z.; Zhao, W.; Gu, X. Changes resulting from a land consolidation project (LCP) and its resource-environment effects: A case study in Tianmen City of Hubei Province, China. Land Use Policy 2014, 40, 74-82. [CrossRef]

44. Jiang, G.; Wang, X.; Yun, W.; Zhang, R. A new system will lead to an optimal path of land consolidation spatial management in China. Land Use Policy 2015, 42, 27-37.

45. Wang, J.; Yan, S.; Guo, Y.; Li, J.; Sun, G. The effects of land consolidation on the ecological connectivity based on ecosystem service value: A case study of Da'an land consolidation project in Jilin province. J. Geogr. Sci. 2015, 25, 603-616. [CrossRef]

46. Parfitt, J.M.B.; Timm, L.C.; Reichardt, K.; Pinto, L.F.S.; Pauletto, E.A.; Castilhos, D.D. Chemical and biological attributes of a lowland soil affected by land leveling. Pesqui. Agropecu. Bras. 2013, 48, 1489-1497. [CrossRef] 
47. Oppermann, B.; Michaelis, W.; Blumenberg, M.; Frerichs, J.; Schulz, H.; Schippers, A.; Beaubien, S.; Krüger, M. Soil microbial community changes as a result of long-term exposure to a natural CO2 vent. Geochim. Cosmochim. Acta 2010, 74, 2697-2716. [CrossRef]

48. Roth, P.J.; Lehndorff, E.; Cao, Z.H.; Zhuang, S.; Bannert, A.; Wissing, L.; Schloter, M.; Kögel-Knabner, I.; Amelung, W. Accumulation of nitrogen and microbial residues during 2000 years of rice paddy and non-paddy soil development in the Yangtze River Delta, China. Glob. Chang. Biol. 2011, 17, 3405-3417. [CrossRef]

49. Yan, X.; Zhou, H.; Zhu, Q.; Wang, X.; Zhang, Y.; Yu, X.; Peng, X. Carbon sequestration efficiency in paddy soil and upland soil under long-term fertilization in southern China. Soil Tillage Res. 2013, 130, 42-51. [CrossRef]

50. Mulqueen, J.; Rodgers, M.; Scally, P. Phosphorus transfer from soil to surface waters. Agric. Water Manag. 2004, 68, 91-105. [CrossRef]

51. Jiang, Y.; Li, S.; Li, R.; Zhang, J.; Liu, Y.; Lv, L.; Zhu, H.; Wu, W.; Li, W. Plant cultivars imprint the rhizosphere bacterial community composition and association networks. Soil Biol. Biochem. 2017, 109, 145-155. [CrossRef]

52. Delgado-Baquerizo, M.; Eldridge, D.J.; Hamonts, K.; Reich, P.B.; Singh, B.K. Experimentally testing the species-habitat size relationship on soil bacteria: A proof of concept. Soil Biol. Biochem. 2018, 123, 200-206. [CrossRef]

53. Unger, I.M.; Goyne, K.W.; Kremer, R.J.; Kennedy, A.C. Microbial community diversity in agroforestry and grass vegetative filter strips. Agrofor. Syst. 2013, 87, 395-402. [CrossRef]

54. Wang, Y.; Zhu, G.; Harhangi, H.R.; Zhu, B.; Jetten, M.S.; Yin, C.; Op den Camp, H.J. Co-occurrence and distribution of nitrite-dependent anaerobic ammonium and methane-oxidizing bacteria in a paddy soil. FEMS Microbiol. Let. 2012, 336, 79-88. [CrossRef] [PubMed]

55. Sahrawat, K.L. Organic matter accumulation in submerged soils. Adv. Agron. 2004, 81, 170-203.

56. Jiang, Y.; Liang, Y.; Li, C.; Wang, F.; Sui, Y.; Suvannang, N.; Zhou, J.; Sun, B. Crop rotations alter bacterial and fungal diversity in paddy soils across East Asia. Soil Biol. Biochem. 2016, 95, 250-261. [CrossRef]

57. Welbaum, G.E.; Sturz, A.V.; Dong, Z.; Nowak, J. Managing soil microorganisms to improve productivity of agro-ecosystems. Crit. Rev. Plant. Sci. 2004, 23, 175-193. [CrossRef]

58. Kragelund, C.; Caterina, L.; Borger, A.; Thelen, K.; Eikelboom, D.; Tandoi, V.; Kong, Y.; Van Der Waarde, J.; Krooneman, J.; Rossetti, S. Identity, abundance and ecophysiology of filamentous Chloroflexi species present in activated sludge treatment plants. FEMS Microbiol. Ecol. 2007, 59, 671-682. [CrossRef]

59. Ferreira, R.; Gaspar, H.; Gonzalez, J.M.; Clara, M.I.; Santana, M.M. Copper and temperature modify microbial communities, ammonium and sulfate release in soil. J. Plant. Nutr. Soil Sci. 2015, 178, 953-962. [CrossRef]

60. He, F.; Yang, B.; Wang, H.; Yan, Q.; Cao, Y.; He, X. Changes in composition and diversity of fungal communities along Quercus mongolica forests developments in Northeast China. Appl. Soil Ecol. 2016, 100, 162-171. [CrossRef]

61. Sterkenburg, E.; Bahr, A.; Durling, M.B.; Clemmensen, K.E.; Lindahl, B.D. Changes in fungal communities along a boreal forest soil fertility gradient. New Phytol. 2015, 207, 1145-1158. [CrossRef]

62. Liu, S.; Mo, X.; Lin, Z.; Xu, Y.; Ji, J.; Wen, G.; Richey, J. Crop yield responses to climate change in the Huang-Huai-Hai Plain of China. Agric. Water Manag. 2010, 97, 1195-1209. [CrossRef]

63. Georgescu, M.; Lobell, D.; Field, C. Potential impact of US biofuels on regional climate. Geophys. Res. Lett. 2009, 36, L21806. [CrossRef]

64. Kreye, C.; Dittert, K.; Zheng, X.; Zhang, X.; Lin, S.; Tao, H.; Sattelmacher, B. Fluxes of methane and nitrous oxide in water-saving rice production in north China. Nutr. Cycl. Agroecosyst. 2007, 77, 293-304. [CrossRef]

65. Yang, R.; Ti, C.; Li, F.; Deng, M.; Yan, X. Assessment of $\mathrm{N}_{2} \mathrm{O}, \mathrm{NO}_{\mathrm{x}}$ and $\mathrm{NH}_{3}$ emissions from a typical rural catchment in Eastern China. Soil Sci. Plant Nutr. 2010, 56, 86-94. [CrossRef]

66. Qin, H.; Tang, Y.; Shen, J.; Wang, C.; Chen, C.; Yang, J.; Liu, Y.; Chen, X.; Li, Y.; Hou, H. Abundance of transcripts of functional gene reflects the inverse relationship between $\mathrm{CH}_{4}$ and $\mathrm{N}_{2} \mathrm{O}$ emissions during mid-season drainage in acidic paddy soil. Biol. Fertil. Soils 2018, 54, 885-895. [CrossRef]

67. Galford, G.L.; Melillo, J.M.; Kicklighter, D.W.; Cronin, T.W.; Cerri, C.E.; Mustard, J.F.; Cerri, C.C. Greenhouse gas emissions from alternative futures of deforestation and agricultural management in the southern Amazon. Proc. Natl. Acad. Sci. USA 2010, 107, 19649-19654. [CrossRef]

68. Zheng, C.; Liu, J.; Cao, G.; Kendy, E.; Wang, H.; Jia, Y. Can China cope with its water crisis?-Perspectives from the North China Plain. Groundwater 2010, 48, 350-354. [CrossRef] 
69. Hu, Y.; Moiwo, J.P.; Yang, Y.; Han, S.; Yang, Y. Agricultural water-saving and sustainable groundwater management in Shijiazhuang Irrigation District, North China Plain. J. Hydrol. 2010, 393, 219-232. [CrossRef]

70. Piao, S.; Ciais, P.; Huang, Y.; Shen, Z.; Peng, S.; Li, J.; Zhou, L.; Liu, H.; Ma, Y.; Ding, Y. The impacts of climate change on water resources and agriculture in China. Nature 2010, 467, 43. [CrossRef]

71. Ding, T.; Qian, W. Geographical patterns and temporal variations of regional dry and wet heatwave events in China during 1960-2008. Adv. Atmos. Sci. 2011, 28, 322-337. [CrossRef]

72. Kueppers, L.M.; Snyder, M.A.; Sloan, L.C. Irrigation cooling effect: Regional climate forcing by land-use change. Geophys. Res. Lett. 2007, 34, L3703. [CrossRef]

73. Qian, Y.; Huang, M.; Yang, B.; Berg, L.K. A modeling study of irrigation effects on surface fluxes and land-air-cloud interactions in the Southern Great Plains. J. Hydrometeorol. 2013, 14, 700-721. [CrossRef]

(C) 2019 by the authors. Licensee MDPI, Basel, Switzerland. This article is an open access article distributed under the terms and conditions of the Creative Commons Attribution (CC BY) license (http://creativecommons.org/licenses/by/4.0/). 